\title{
Brazilian spotted fever in Caratinga, Minas Gerais
}

\section{Febre maculosa Brasileira em Caratinga, Minas Gerais}

\author{
Márcio Antonio Moreira Galvão', Cláudio Lisias Mafra de Siqueira² ${ }^{2}$ Renata Nascimento de Freitas ${ }^{3}$, \\ Luciane Daniele Cardoso ${ }^{4}$, Amanda de Freitas Padilha ${ }^{5}$, Edvaldo Barros ${ }^{6}$
}

DOI: $10.5935 / 2238-3182.20140096$

\section{ABSTRACT}

Introduction: The order Rickettsiales comprises a group of obligatory intracellular parasites, responsible for causing diseases known as rickettsial diseases. In Brazil, the most common rickettsial disease is the Brazilian spotted fever (FMB). Objectives: to determine the level of FMB endemicity in the city of Caratinga, Minas Gerais, in different epidemiological moments. Methods: epidemiological and serological surveys in residents from the most affected neighborhoods by the 1992 FMB outbreak and serological survey in domestic animals; in addition to serological survey in domestic animals and polymerase chain reaction in arthropod vectors collected in a new visit to the site in 2002. Results: in the first epidemiological survey carried out in 1992, 62.3\% of the surveyed families reported contact with pastures. In the serological survey in humans, $2.1 \%$ of tested samples showed reactivity to Rickettsia rickettsii in the indirect immunofluorescence reaction (RIFI). In the serological survey on animals, conducted in $1993,53.4 \%$ of equines and $25.0 \%$ of dogs were reactive for R. Rickettsii in RIFI. In a new visit to the site, over the period of 2002-2003, $13.4 \%$ of pools of DNA from examined arthropods and $17.0 \%$ of equine sera demonstrated positive results for R. rickettsii. Conclusions: the municipality of Caratinga can be considered, at the time, as a low transmission area remaining the recommendation to keep the epidemiological and acarological surveillance system active on the site and region.

Key words: Rocky Mountain Spotted Fever; Rickettsia rickettsia; Ticks; Acari; Health Surveillance.

\section{RESUMO}

Introdução: a Ordem Rickettsiales abriga um grupo de parasitas intracelulares obrigatórios, responsáveis por causar doenças conhecidas como riquetsioses. No Brasil, a riquetsiose mais comum é a febre maculosa brasileira (FMB). Objetivos: determinar o nível de endemicidade para a FMB no município de Caratinga, Minas Gerais, em diferentes momentos epidemiológicos. Métodos: inquéritos epidemiológico e sorológico em moradores dos bairros mais afetados pelo surto de FMB de 1992 e sorológico em animais domésticos; além de sorológico em animais domésticos e reação em cadeia de polimerase em artrópodes vetores coletados em nova visita ao foco em 2002. Resultados: no primeiro inquérito epidemiológico realizado em 1992, $62,3 \%$ das famílias pesquisadas relataram contato com pastos. No inquérito sorológico em humanos, 2,1\% das amostras testadas apresentaram reatividade para Rickettsia rickettsii à reação de imunofluorescência indireta (RIFI). No inquérito sorológico em animais, realizado em 1993, 53,4\% dos equinos e 25,0\% dos cães foram reativos para R. Rickettsii à RIFI. Em nova visita ao foco, no período de 2002-2003, 13,4\% dos pools de DNA dos artrópodes examinados e 17,0\% dos soros equinos demonstraram resultados positivos para $R$. rickettsii. Conclusões: o município de Caratinga pode ser considerado, no momento, área de baixa transmissão, permanecendo a reco-
${ }^{1}$ MD. Ph.D. in Public Health. Full Professor at the School of Medicine from the Federal University of Ouro Preto UFOP. Ouro Preto, MG - Brazil.

${ }^{2}$ Veterinarian. PhD in Biochemistry. Associate Professor in the Department of Biochemistry and Molecular Biology from the Federal University of Viçosa - UFV. Viçosa, MG - Brazil. ${ }^{3}$ Nutritionist. PhD in Biochemistry and Immunology. Associate Professor at the School of Nutrition and Coordinator of the Center for Research in Biological Sciences (NUPEB) from the Federal University of Ouro Preto UFOP. Ouro Preto, MG - Brazil.

${ }^{4}$ Nutritionist. PhD in Health Sciences. Adjunct Professor in the Department of Pharmacy and Nutrition at the Federal University of Espirito Santo - UFES. Alegre, ES - Brazil. ${ }^{5}$ Biologist. Master in Structural and Physiological Biochemistry. PhD student in the Center for Research in Biological Sciences from the Federal University of Ouro Preto - UFOP. Ouro Preto, MG - Brazil.

${ }^{6}$ Biologist. Master degree in Agricultural Biochemistry. College graduated technician at the Federal University of Viçosa - UFV. Viçosa, MG - Brazil.

\author{
Submitted: 2013/22/01 \\ Approved: 2014/21/05 \\ Institution \\ The Federal University of Ouro Preto, School of Medicine \\ Laboratory of Zoonoses \\ Ouro Preto, $\mathrm{MG}$-Brazil \\ Corresponding Author: \\ Márcio Antônio Moreira Galvão \\ E-mail: galvaomarcio@oi.com.br
}


mendação de se manter ativo o sistema de vigilância epidemiológica e acarológica no local e região.

Palavras-chave: Febre Maculosa das Montanhas Rochosas; Rickettsia rickettsii; Carrapatos; Ácaros e Carrapatos; Vigilância Epidemiológica.

\section{INTRODUCTION}

Rickettsioses are diseases caused by bacteria from the order Rickettsiales composed of the families: (1) Rickettsiaceae, with the genera Rickettsia and Orientia and (2) Anaplasmataceae, with the genera Anaplasma, Erlichia, Neorickettsia, Wolbachia, and Aegyptianella. ${ }^{1}$

Diseases caused by the genus Rickettsia are arousing great scientific interest in recent years. The advent of molecular biology has provided important clarifications concerning various aspects previously confusing in this group of microorganisms. ${ }^{2}$

The genus Rickettsia is traditionally divided into three groups based on antigenic and genetic characteristics:

n the typhus group (TG): that includes the species Rickettsia prowazekii, the agent of typhus exanthematicus epidemic, and Rickettsia typhi, causal agent of murine typhus;

- the spotted fever group (SFG): that includes many serotypes such as Rickettsia rickettsii, the etiologic agent of Rocky Mountain spotted fever and Brazilian spotted fever; Rickettsia conorii, the etiologic agent of the Mediterranean fever; Rickettsia felis, the etiologic egent of felis rickettsioses; and Rickettsia akari, the etiologic egent of rickettsialpox;

- the ancestral group (AG): composed by the Rickettsia bellii and Rickettsia canadensis species. A fourth group was recently proposed, called a transition group, comprising species previously belonging to the SFG, such as the species $R$. akari, Rickettsia australis, and $R$. felis; the validity of this group is still being debated. ${ }^{3}$

Among the SFG rickettsioses in Brazil, the Brazilian Rocky Mountain spotted fever (BRMSF) stands out as the most common and lethal. Its etiological agent is the bacteria $R$. rickettsii and its main vector is the tick Amblyomma cajennense, which is a highly anthropophilic ectoparasite species. ${ }^{4}$

In humans, after inoculation, rickettsia installs itself in endothelial cells of small vessels and blood capillaries causing injuries that lead to loss of integrity of vessels and capillaries' walls allowing the passage of blood to extravascular tissues. Thus, commonly observed intra-tissue bleeding occurs. ${ }^{5}$ Its nonspecific symptoms such as high fever, myalgia, and headache makes its diagnosis of differentiation with other febrile and exanthematic diseases difficult, especially those as dengue, leptospirosis, measles, typhoid fever, infectious mononucleosis, yellow fever, and hantavirose.

In Brazil, the first description of the bacterium $R$. rickettsii was in the city of São Paulo by Piza ${ }^{8}$ who framed it as the agent of BRMSF, known as exanthematic typhus of São Paulo at the time, transmitted by the tick Amblyomma cajennense. ${ }^{6}$ Piza also demonstrated its similarity with Rocky Mountain spotted fever described by Ricketts ${ }^{9}$ in the United States. Between 1932 and 1952, researchers like Monteiro ${ }^{10}$, Dias, and Martins $^{11}$, Travassos ${ }^{12}$ and Magalhães ${ }^{13}$ described new cases of rickettsioses in Minas Gerais and São Paulo.

There was an epidemiological silence between 1953 and 1980 in Brazil, with the absence of reports of cases of BRMSF. However, from late 1980, new discoveries revitalized the scientific knowledge about this rickettsiosis. ${ }^{12-14}$

In October of 1992, the State Secretary of Health of the State of Minas Gerais was notified about the occurrence of 15 deaths in the municipality of Caratinga, in the eastern region of the state. The cases occurred between June and October, with the diagnosis of Rocky Mountain spotted fever as the most likely explanation of the deaths based on clinical, epidemiological, and serological criteria.

The patients generally presented high fever symptoms of sudden onset, headache, myalgia, vomiting, and diarrhea. Some displayed maculopapular exanthema rash from the third day of illness. The evolution to septicemia and death occurred in less than seven days.

\section{MATERIALS AND METHODS}

Epidemiological and serological surveys were conducted on 12/16/1992, 48 days after the occurrence of the last suspected case in the Cadeia neighborhood of Caratinga, Minas Gerais. This neighborhood was selected because it showed the highest number of cases in the outbreak.

- epidemiological survey: the epidemiological survey was conducted through a questionnaire applied to 93 households. The houses were visited by interviewers who asked questions about the location of residence, personal and socio-economic data of the respondent, and to the presence or absence of suspicious deaths by BRMSF in the residence; 
- serological investigation: samples of $10 \mathrm{~mL}$ of venous blood were collected from 244 people from the 93 visited households (approximately $55.3 \%$ of the total population in the visited area). The serum was obtained by centrifugation of the blood sample and stored at $-20{ }^{\circ} \mathrm{C}$. Sera were subsequently submitted to RIFI for $R$. rickettsii detection considering the titration of at least 1:64 as the cutoff point, according to the Centers for Disease Control and Prevention (CDC) in Atlanta (USA);

- vectors investigation: vectors were collected in horses and dogs in the nearby places from the interviewed household by a duly trained team from the office of the National Health Foundation (FUNASA) in the same municipality. Ticks were collected on 6/22 and 6/23/1993 through search and grooming on the surface of the body of animals in the houses and nearby habitats. After manually collected, the ectoparasites were packed and identified according to location and animal origin. These arthropods were taxonomically identified using the dichotomous and a pictorial key described by Aragão and Fonseca:15

n post-epidemic monitoring: the post-epidemic monitoring was conducted by surveying suspicions notifications of BRMSF cases to the Secretary of Health of the City of Caratinga for the population in the entire municipality between 1992 and 2002. Serologic test results conducted for the selected population by the Ezekiel Dias Foundation were also surveyed over the same period. In addition, serological investigation in horses and dogs was conducted between May 2002 and April 2003 in the area affected by the epidemic of 1992 and collection of ticks and fleas was performed through grooming on the body surface of domestic animals in the same area (dogs and cats). The taxonomic identification of ticks followed the dichotomous and a pictorial key described by Aragão and Fonseca. ${ }^{15}$ Fleas were identified morphologically according to Linardi and Guimarães, ${ }^{16}$

- molecular research: fleas and ticks collected from animals underwent DNA extraction and PCR.

\section{RESULTS}

The epidemiological survey showed that 60 out of the 93 (64.52\%) surveyed households had proximity to pastures, which exposed residents to the risk of contact with ticks. Horses, dogs, and cats were found in 3 (3.23\%), 30 (32.26\%), and 26 (27.96\%) of the surveyed households, respectively.

Contact with the pasture was reported by 58 families (62.37\%); 33 of them (56.80\%) reported a virtually daily contact in order to fetch water, firewood, or dung; 9 (15.52\%) for recreation; 6 (10.34\%) to reach workplaces; 4 (6.90\%) to hang clothes to dry; 3 (5.17\%) to lead and seek animals; 2 (3.45\%) to discard trash; and 1 (1.72) to work on the land next to the cemetery.

In all households in which there were deaths suspected of Rocky Mountain spotted fever, contact with the pasture was constant (to fetch firewood or for recreation). In one of those households, one case of positive serology for Rocky Mountain spotted fever was reported during the investigation (Tables 1, 2, and 3).

Table 1 - Reactivity to RIFI for Rickettsia rickettsia during the serological survey in the population of the Cadeia neighborhood in Caratinga, Minas Gerais, 1992

\begin{tabular}{l|c}
\multicolumn{1}{c}{ Titer } & $\begin{array}{c}\text { RIFI for Rickettsia rickettsia } \\
(\mathrm{n}=232)\end{array}$ \\
$\geq 1: 64$ & $5(2.16 \%)$ \\
$<1: 64$ & $17(7.33 \%)$ \\
\hline Total positive samples & $22(9.49 \%)$ \\
\hline
\end{tabular}

Table 2 - Reactivity to RIFI for Rickettsia rickettsia in horse sera collected in June of 1993 in the municipality of Caratinga, Minas Gerais

\begin{tabular}{l|cc}
\multicolumn{1}{c}{ Samples } & RIFI & \\
& IgM & IgG \\
\hline Total tested samples & --- & 28 \\
\hline Total reactive samples (a) & --- & 15 \\
\hline Percentage (\%) of reactive samples & --- & 53.40 \\
\hline
\end{tabular}

(a) Serum considered reactive showed titers $\geq 1: 64$ in RIFI.

Table 3 - Reactivity to RIFI for Rickettsia rickettsia in dog sera collected in June of 1993 in the municipality of Caratinga, Minas Gerais

\begin{tabular}{l|cc}
\multicolumn{1}{c}{ Samples } & \multicolumn{2}{c}{ RIFI } \\
\hline Total tested samples & IgM & IgG \\
\hline Total reactive samples $\geq 1: 64$ & --- & 44 \\
\hline Percentage (\%) of reactive samples & --- & 11 \\
\hline
\end{tabular}

The investigation on vectors was hampered due to the implementation of control measures at the beginning of the epidemic by the Epidemiological Surveillance Service of the municipality, such as the use of tickicides. In spite of this, 172 ticks were collected from 29 horses and 
four dogs between 6/22 and 6/23/1993. These ectoparasites were identified as larvae, nymphs, or adults of Rhipicephalus sanguineus and Amblyomma spp. (Table 4).

A total of 116 suspected cases and 15 deaths were reported and confirmed for BRMSF in the year of the outbreak (1992). In the post-outbreak period (1993 to 2002), 193 suspected BRMSF cases were reported in Caratinga; most of these notifications were concentrated in the second half of each year in this period.

Serological analyses were carried out in 182 samples collected from 193 suspected BRMSF cases reported since 1993. RIFI was used in 60 cases, ELISA in two, and the reaction of Weil Felix in the other 120 samples. Two cases showed positivity with high titles in RIFI in the years 1994 (1:256) and 1996 (1:128), clinically compatible with the BRMSF.

Two cases of suspected murine typhus with titers of 1:800 and 1:600 were verified in 1994. These two cases had initially suspicious diagnoses of Rocky Mountain spotted fever; one of them was from the countryside and the other from the Santa Cruz district (Alto da Antena), an urban area close to the main searched area and where cases of Rocky Mountain spotted fever were recorded during the outbreak of 1992.

In the reevaluation of the Caratinga focus in the period from 2002 to $2003,2,620$ ectoparasites were collected, 2,241 ticks (85.5\%), and 379 fleas (14.5\%). The ticks were found at three developmental stages (larvae, nymphs, and adults); the adult forms (1,535 individuals) made up $68 \%$ of the total. The following species were identified among adult ticks parasitizing horses and dogs: A. cajennense (73\%), $R$. sanguineus (23\%), and Anocentor nitens (4\%). Fleas were identified as belonging to the genus Ctenocephalides and were found parasitizing dogs and cats. These ectoparasites were gathered in 119 pools. DNA extraction and analysis through PCR were conducted. The positive result for the genus Rickettsia was found in 16 pools, of which, 6 came from fleas and 10 from ticks.
Serological survey was also conducted in dogs and horses. None of the tested dog sera $(n=73)$ presented positive result for RIFI, while 3 out of the 18 equine sera (17\%) were positive in the titers 1:64 $(n=1)$ and 1:128 $(n=2)$.

\section{DISCUSSION}

Fleas from the genus Ctenocephalides infected with $R$. felis, detected through PCR, constitute evidence that $R$. felis can be the species with epidemiological importance in the studied region, indicating the possibility of emergence of other human rickettsioses in the region, in addition to certifying the potentiality of fleas as vectors in the transmission of these diseases.

The tick species $A$. cajennense identified in the studied region is considered to be the main vector of Rocky Mountain spotted fever. ${ }^{17}$ Ticks of the species $R$. sanguineus infected by $R$. felis are an unprecedented fact in the literature. The presence of $R$. felis in ticks of the species A. cajennense had already been described earlier. ${ }^{18}$ These recent findings are of great importance because the same bacteria had not been described in more than one vector.

The species $R$. sanguineus was found in dogs and horses, which alerts for the possibility of the participation of these animals in the epidemiology of rickettsioses in the region; these animals maintain close contact with men and may have an important role in the epidemiological chain of Rocky Mountain spotted fever.

The absence of positive serology in the evaluated dogs coupled with the absence of human cases diagnosed on the spot and at the time of the epidemiological evaluation (new visit to the site in 2002) seems important for the characterization of a silent focus. However, the reactivity in horses, considering the role of these animals as sentinels of the disease, and the molecular detection of pathogenic rickettsia in arthropod vectors indicate the need to maintain a system of epidemiological and mites' surveillance on site and in the region.

Table 4 - Ticks collected in dogs and horses in the Cadeia neighborhood in Caratinga, Minas Gerais, in the period of 06/22 and 06/23/1993

\begin{tabular}{|c|c|c|c|c|}
\hline Animal & Quantity (n) & Species & Developmental stage & Quantity (n) \\
\hline \multirow{3}{*}{ Dogs } & \multirow{3}{*}{04} & Rhipicephalus & Larvae & 18 \\
\hline & & \multirow{2}{*}{ sanguineus } & Nimphs & 12 \\
\hline & & & Adults & 15 \\
\hline \multirow{3}{*}{ Horses } & \multirow{3}{*}{29} & \multirow{3}{*}{ Amblyomma spp. } & Larvae & 35 \\
\hline & & & Nimphs & 13 \\
\hline & & & Adults & 79 \\
\hline
\end{tabular}


Despite the serological and molecular detection of pathogenic rickettsiae in domestic animals and their ectoparasites, there was no systematic record of cases of Rocky Mountain spotted fever in the region in the 13 years prior to the completion of this study in 2004. The focus has behaved as a silent focus after 1996, with most of the suspected cases recorded in 1993, 1994, and 1995, years close to the outbreak. Considering the negative serology in a large proportion of cases occurring in those post-epidemic years, it can be concluded that the observed result reflects the state of alarm of the local population before the outbreak of 1992 with its high lethality.

The municipality of Caratinga was evaluated until now as an area of low transmission, however, the use of an epidemiological and mites' surveillance system is recommended.

\section{CONCLUSION}

The detection of rickettsiae in new vectors, such as $R$. felis in ticks of the species $A$. cajennense and $R$. sanguineus, brings a new epidemiological reality in which the specificity of rickettsia type involved with a given vector is no longer valid, i.e. previously rickettsiae reported as transmitted by fleas and lice could also be transmitted by ticks. ${ }^{18-20}$ This new reality brought to light by molecular biology sets a new scenario and brings new actors into the universe of rickettsioses. The debate of vertebrate hosts and reservoirs of rickettsioses also imposes itself as a dominant discussion that questions the role of wild animals such as capybara, rodents, and marsupials in the epidemiological cycle of riquetsioses. ${ }^{21-23}$

\section{REFERENCES}

1. Dumler JS, Barbet AF, Bekker CP, Dasch GA, Palmer GH, Ray SC. Reorganization of genera in the families' Rickettsiaceae and Anaplasmataceae in the order Rickettsiales. Int J Syst Evol Microbiol. 2001; 51:2145-65.

2. La Scola B, Raoult D. Laboratory diagnosis of rickettsioses: current approaches to diagnosis of old and new rickettsial diseases. J Clin Microbiol. 1997;35(27):15-27.

3. Hun L, Troyo A. An update of the detection and treatment of Rickettsia felis. Res Rep Trop Med. 2012 Jun; 3:47-55.

4. Dantas-Torres FRocky mountain spotted fever. Lancet Infect Dis. 2007; 7:724-32.

5. Azad AF,Beard CB. Rickettsial diseases and their arthropod vectors. Emerg Infect Dis. 1998; 4:179-86.
6. Raoult D, Berbis P,Roux V,Xu W,Maurin M.A new tick-transmitted disease due to Rickettsia slovaca. Lancet. 1997; 350:112-13.

7. Roux V, Fournier PE, Rydkina E, Raoult D. Philogenetic study of the Rickettsiaceae. In: Rickettsia and Rickettsial Diseases. Bratislava:Veda; 1996. p. 34-42.

8. Piza JT. Considerações epidemiológicas e clínicas sobre o Tifo Exantemático de São Paulo.Soc Imp Paulista. 1932; 1:11-119.

9. Ricketts HT. Some aspects of Rocky Mountain spotted fever as shown by recent invesigations. Med Record. 1909; 76:843-55.

10. Monteiro JL, Fonseca FTypho exantemático de São Paulo. XII. Sobre um "vírus" isolados de ratos da zona urbana da cidade e suas relações com o typho exantemático de S.Paulo. Brasil-Médico. 1932;46:1029-33.

11. Dias E, Martins AV. Spotted fever in Brazil - a summmary. Am J Trop Med Hyg. 1939; 19:103-8.

12. Travassos J, Rodrigues PM, Carrijo LN.Tifo murino em São Paulo. Identificação da Rickettsia mooseri isolada de um caso humano. Mem Inst Butantã. 1949; 1:77-106.

13. Magalhães O. Contribuição ao conhecimento das doenças do grupo exantemático. Brasília: Imprensa Nacional; 1952.

14. Gonçalves AJR, Lopes PFA, Melo JCP, Pereira AA, Pinto AMM, Lazera MS, et al. Rickettsioses - A propósito de quatro casos diagnosticados no Rio de Janeiro de febre maculosa brasileira. Folha Médica. 1981; 82(2):127-34.

15. Galvão MAM, Mendonça EF,Teixeira RI, Dutra AJL, Host HH, Costa PRR. Relato de investigação epidemiológica de um provável surto de rickettsiose em Grão Mogol,Minas Gerais.Cad Internato Rural. 1983;2(1):61-79.

16. Melles HHB, Colombo S, Silva MV. Febre maculosa: isolamento de Rickettsia em amostra de biópsia de pele. Rev Inst Méd Trop São Paulo. 1992;34(1):37-41.

17. Aragão HB,Fonseca FNotas de Ixidologia VIII. Lista e chave para os representantes da fauna ixodológica brasileira. Mem Inst Oswaldo Cruz. 1961; 59:115-29.

18. Linardi PM,Guimarães LR.Sifonápteros do Brasil.São Paulo: Museu de Zoologia Universidade de São Paulo/ FAPESP; 2000.291p.

19. Galvão MAM, Ribeiro JGL, Machado-Pinto J. Rickettsioses. In: Tonelli E, Freire LMS. Doenças infecciosas na infância e na adolescência. Rio de Janeiro: MEDSI; 2000.

20. Galvão MAM, Bouyer DH, Olano JP,Cerqueira R, Walker DH. Rickettsia felisin Amblyomma cajennense ticks, Brazil. Proceedings of 3th International Conference on Rickettsiae and Rickettsial Diseases. Slovenia: Ljubljana; 2002.p.103.

21. Cardoso LD, Galvão MAM, Freitas RN, Mafra CL, Neves CVB, Bacellar FC, et al.Caracterização de Rickettsia spp.Circulante em foco silencioso de febre maculosa brasileira no Município de Caratinga, Minas Gerais, Brasil. Cad Saúde Pública. 2006; 22(3):495-501.

22. Sanchez-Medina A, Bouyer DH, Mafra CL, Zavala-Castro J, Whitworth T, Popov VL, et al. Discovery of a thyphus group Rickettsia in Amblyomma ticks in the state of Nuevo Leon, Mexico. Proceedings of 4th International Conference on Rickettsiae and Rickettsial Diseases, Spain: Logroño; 2005. p.53.

23. Galvão MAM, Cardoso LD, Mafra CL, Walker DH. Revisiting Brazilian spotted fever focus of Caratinga, Minas Gerais state.Proceedings of 4th International Conference on Rickettsiae and Rickettsial Diseases. Spain: Logroño; 2005. p. 162. 